\title{
Exploring factors affecting the Greek high school students' participation in Geographical and Environmental Research Project using social Web 2.0 applications. A case study
}

\author{
Evi Exarchou ${ }^{1}$, Aikaterini Klonari ${ }^{2}$ \\ ${ }^{\prime}$ (PhD Candidate, Department of Geography, University of the Aegean, Greece) \\ ${ }^{2}$ (Assistant professor, Department of Geography, University of the Aegean, Greece)
}

\begin{abstract}
This study is a continuation of the previous year's work on the analysis of sociocultural constructivist interactions of Greek high school students $(N=16)$ during an eight-month geographical and environmental research project in a social computing and specifically a free social bookmarking site, Diigo. All learning actions led students to reach the higher phase of sociocultural constructivist interaction, progressively developing essential geographic skills, creating an active social network (with remarkable distinction in the cohesion, power and role structures). The results also showed that the density value of students' interaction and the quality of their discussion were at a satisfactory level with most complete exchanges, throughout the project. However, there were significant differences in individual participation rates of students in the exploratory process (i.e., inactive, moderate, and active). This was important information for us and we needed to further explore the factors affecting the students' participation in corresponding actions. Searching the literature, we identified the factors, such as students' course performance, previous experience and a variety of sociodemographic characteristics with potential influence on their participation. Thus in this study, we correlated the activity and quality of students' project participation with the above factors. The results of correlation analysis suggest that their participation level was positively and significantly correlated with their previous experience in geographical and environmental actions at the 0.01 level. Also, their participation level was positively related to their gender and parental education level. On the other hand, there were negative but at a moderate level of correlation between their participation level and their performance in courses theoretical direction and financial stability.
\end{abstract}

Keywords: Learner participation, Geographical and Environmental Research Project, Social Web 2.0, Sociocultural Constructivist Interaction

\section{Introduction}

According to many authors $[1,2,3,4,5,6,7]$ constructivist, collaborative and social learning theories are becoming widely accepted in all fields of educational audience, including the application of Web 2.0 technologies to teaching and learning. The current social Web 2.0 era has the potential to support educational innovation and change by creating an online learning community, promoting the opening of the school in society, through multilateral, cooperative and flexible curricular activities $[8,9,10]$. For example, the social networking tools support the online learning communities in which knowledge is communicated and shared through learner-learner interaction with instantly accessibility to a broader network of users and also characterized as integral to participation in cultural practices and distributed in social relations and activities [11, $12,13,14,15]$. Furthermore, a study of great interest is the review of Michinov et al. [16] regarding the impact of learner participation to create an effective learning community. Making reference to recent literature, they note that "learning in an online environment is most successful when students feel that they participate and when they participate effectively. For example, some research suggests that students who fail tend to interact less frequently with their peers than those who succeed". They also recognize that the learner participation in these communities influences a wide range of learning outcomes and plays an important role both in reducing the physical and psychological isolation of learners, because of the mutual psychological support, safety and shared responsibility. Vonderwell and Zachariah [17] argue that monitoring student participation and patterns of participation closely can help instructors identify student needs and scaffold learning accordingly. However, they note that participation is more than the total number of student postings in a discussion forum and a definition of online learner participation that acknowledges its more complex dimensions, such as doing, communicating, thinking, feeling, and belonging, is proposed in the Hrastinski paper [18].

The purpose of the present study was to explore what factors influenced students' participation during an eight-month geographical and environmental research project of Greek high school students' sample, using the new applications and extensions of the social Web 2.0 and specifically a free social bookmarking site, Diigo 
[19]. All the learning actions led sample to create an active social network (with remarkable distinction in the cohesion, power and role structures) and reached the higher phase of sociocultural constructivist interaction (with most complete exchanges throughout the project), progressively developing essential skills for an organized and integrated geographical and environmental approach to the research issue. However, there were significant differences in individual participation rates of students in the exploratory process (i.e., inactive, moderate, and active) [20]. A variety of factors affecting the students' project participation level can be identified in the literature. Vonderwell and Zachariah [17] searched for factors that influence learner participation and they found that online learner participation are influenced by technology and interface characteristics, content area experience, student roles and instructional tasks, and information overload. In another study conducted by Vrasidas and McIsaac [21] who examined the nature of interaction in an online course from both teacher and student perspectives and they concluded that the structure of course, class size, feedback, and prior knowledge of computer mediated communication all affected the interaction. Moreover, there are other important aspects that influence student's participation and one of them is related to the differences in students' sociodemographics and abilities in online courses. For example, Godwin, Thorpe and Richardson [22] mentioned that students participating online courses with a high level of interaction tended to be different from others participating the courses with a low level of interaction in regard to age, gender and previous qualifications. Although the results were not statistically significant, high interactive students were generally younger, male and having had higher educational qualifications. Another study by Yukselturk [23] examined the relationship between the students' individual demographics and categories of students' participation level (inactive, moderate, and active) in a course through online survey. The results of the above study indicated that three student characteristics (achievement, gender and weekly hours of Internet use) showed a significant relationship with students' participation level in discussion forum of the online course. Also, taking into account that in this study, it is explored students' participation level in a geographic and environmental education school online project, we identified earlier studies $[24,25,26]$ in which a variety of students' sociodemographic variables are included in the analysis of their participation in geographic and spatial activities. For example, Montello et al. [24] review the extensive multidisciplinary literature on sex-related differences in spatial abilities, emphasizing results that are most relevant to the development of geographic knowledge. Researchers then present the results of a study designed to compare the sexes on a wide array of spatial and geographic tasks. Concluding this part, it is noted that effective online learning process requires interdependence for a shared understanding of learning goals in a learning community. Monitoring students' participation in the process and exploring the factors affecting this can help instructors identify student needs and scaffold learning accordingly [17].

\section{Methodology}

This study is a continuation of the previous year's work [20,31,32] in which we designed a case study transdisciplinary research $(\mathrm{TdR})$ project that enabled students to explore a geographical and environmental issue, using Diigo, in the frame of socialcultural constructivist pedagogy and active- collaborative learning. At the beginning of the project, students answered questions about their course performance, previous experience (geographical and environmental actions and use of social web tools) and sociodemographic characteristics (gender and social status of families). The focus participants of the project were 16 Greek high school students, 10 females and 6 males (aged 15 - 16). They also varied in their socioeconomic and cognitive background. Before the program, most students had a previous experience in geographical and environmental actions, while half had used social computing for educational and research purposes. The project lasted 29 weeks (from October 2011 to May 2012), 3h per week in computer lab. The sample worked in groups of four, and each group had two PC to use. To better understand these community activities, we conducted the quantitative content analysis (QCA) and social network analysis (SNA), using the community learning exchanges through shared bookmarks, tags, annotations, interactive sticky notes, digital highlights, images and documents. The number of learning exchanges was 312 at the end of May. The active students in the project had more than twenty six learning exchanges and the most connections to others, creating a dynamic research group and enhancing the exploratory process. Moderate participants had less than twenty four learning exchanges and inactive students in this study had not any learning exchanges and they only read shared learning exchanges from certain students. These three groups of students (inactive, moderate and active) indicated the students' participation level. Regarding study variables, the students' participation level in the project was the dependent variable and the students' course performance, previous experience and a variety of sociodemographic characteristics were all independent variables. The list of independent variables, percentage, descriptions, and categories of these variables are presented in Table 2 . 
Table 2. Description and Categories of Independent Variables

\begin{tabular}{|c|c|c|}
\hline Variables & Description & $\begin{array}{l}\text { Categories and Percentage of } \\
\text { participants }(\%)\end{array}$ \\
\hline \multicolumn{3}{|l|}{ Course performance } \\
\hline $\begin{array}{l}\text { 1. Theoretical direction } \\
\text { 2.Technological direction } \\
\text { 3. Sciences }\end{array}$ & $\begin{array}{l}\text { Indicates the students performance in courses } \\
\text { theoretical direction, technological direction } \\
\text { and sciences }\end{array}$ & $\begin{array}{l}\text { 1, excellent }(n=18.75) ; 3, \text { sufficient } \\
(n=50) \\
1, \text { excellent }(n=12.5) ; 3, \text { sufficient } \\
(n=6,25) \\
1, \text { excellent }(n=) ; 3, \text { sufficient }(n=)\end{array}$ \\
\hline \multicolumn{3}{|l|}{ Previous experience } \\
\hline $\begin{array}{l}\text { 4. Geographical and } \\
\text { environmental actions }\end{array}$ & $\begin{array}{l}\text { Indicates whether students had geographical } \\
\text { and environmental experience before }\end{array}$ & 1, yes $(\mathrm{n}=18.75) ; 0$, no $(\mathrm{n}=12.5)$ \\
\hline 5. Use of social web tools & $\begin{array}{l}\text { Indicates whether students used social web } \\
\text { tools before }\end{array}$ & 1, yes $(\mathrm{n}=50) ; 0$, no $(\mathrm{n}=50)$ \\
\hline \multicolumn{3}{|c|}{ Sociodemographic characteristics } \\
\hline 6. Gender & Sex of students & 1, female $(n=37.5) ; 0$, male $(n=62.5)$ \\
\hline \multicolumn{3}{|l|}{ Social status of families } \\
\hline 7. Financial stability & $\begin{array}{l}\text { Students' responses to maintain or not their } \\
\text { parents work, their activities/ hobbies in recent } \\
\text { years. }\end{array}$ & $\begin{array}{l}\text { 1, confident }(n=37.5) ; 4, \text { not confident } \\
(n=62.5)\end{array}$ \\
\hline 8. Parental education level & Education level of parents & $\begin{array}{l}\text { 1, graduate }(n=12.5) ; 5, \text { less than high } \\
\text { school degree }(n=6.25)\end{array}$ \\
\hline
\end{tabular}

\section{Results}

Pearson correlation analysis was applied to examine the relationship between the activity and quality of students' project participation and their course performance, previous experience and a variety of sociodemographic characteristics. As seen in Table 2, the results of correlation analysis suggest that the dependent variable of the study was positively and significantly correlated $(\mathrm{r}=.519)$ with the previous experience in geographical and environmental actions at the 0.01 level. The visualization of the social network confirmed the above results because the most members with previous experience in fourth factor (colored nodes) had central position (active role) in the network, creating most connections to the other members of the network and activating other members, regardless of the group. Also, the students' project participation level was positively related to their gender and parental education level with coefficients of .141 and .313 respectively. On the other hand, there were negative but at a moderate level of correlation between the above dependent variable and their performance in courses theoretical direction $(\mathrm{r}=-.342)$ and financial stability $(\mathrm{r}=-.236)$.

Table 2. Pearson product-moment correlations between students' participation in the project and the factors with visualization of the network

\begin{tabular}{|c|c|c|}
\hline $\begin{array}{l}\text { Factors affecting } \\
\text { students' participation }\end{array}$ & $\begin{array}{l}\text { Participation } \\
\text { Pearson }(r)\end{array}$ & $\begin{array}{l}\text { Students' interaction } \\
\text { Nodes represent the students, while edges indicate their } \\
\text { learning exchanges. }\end{array}$ \\
\hline $\begin{array}{l}\text { Course performance } \\
\text { 1. Theoretical direction } \\
\text { 2. Technological direction } \\
\text { 3. Sciences }\end{array}$ & $\begin{array}{r}-.342 \\
.046 \\
.089 \\
\end{array}$ & \\
\hline $\begin{array}{l}\text { Previous experience } \\
\text { 4. Geographical and } \\
\text { environmental actions } \\
\text { 5. Use of social web tools }\end{array}$ & $\begin{array}{r}.519 * \\
.015 \\
\end{array}$ & \\
\hline $\begin{array}{l}\text { Sociodemographic characteristics } \\
\text { 6. Gender } \\
\text { Social status of families } \\
\text { 7. Financial stability } \\
\text { 8. Parental education level }\end{array}$ & $\begin{array}{r}.141 \\
-.236 \\
.313\end{array}$ & 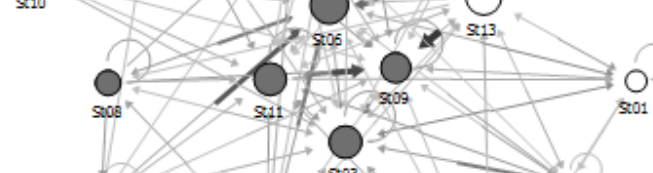 \\
\hline $\begin{array}{l}\text { *. Correlation is significant at the } 0.01 \text { level } \\
\text { (2-tailed). }\end{array}$ & & $\begin{array}{l}\text { The color and size of nudes indicate the students with } \\
\text { previous experience in fourth factor and central role in } \\
\text { network, respectively. The weight of edges shows the } \\
\text { amount of learning exchanges. }\end{array}$ \\
\hline
\end{tabular}

Note. For conducting the analysis and visualization of the social network was used the Cyram NetMiner 4.0 program [33]. 


\section{Discussion Of Research Findings}

Making reference to Vrasidas \& McIsaac [21],Yukselturk [23] note that one of the key components of good teaching is meaningful interaction with peers and teachers and their participation is a prerequisite for supplying interaction and communication in online courses. However, there were significant differences in individual participation rates of students in the online learning process (i.e., inactive, moderate, and active). This was important information for us and we examined factors affecting students' participation in corresponding actions. From eight characteristics of students examined, only one of them (the previous experience in geographical and environmental actions) showed a positive and significant relationship with students' participation level in the project (i.e., inactive, moderate, and active). This finding was consistent with past research $[17,34,35,36,37,38,39,40,41]$ in which the previous activities, experiences and thoughts of students had an effect on their participation level in sociocultural constructivist on line learning environments. In learning processes, students made connections between the new knowledge and existing ones. Regarding previous experience in geographical and environmental education school programs, Liarakou et al. [42] argue that this appears to be a critical factor since it has clearly influenced students' ideas in a positive way. Also, the existing participation per se in such programs acts decisively on students' participation level with interesting ideas in corresponding actions even though the core subject may be unknown to them. Returning to our study, students' participation level was positively related to their gender and parental education level. In the literature, gender and education of parents based differences in online education have been recognized as positive factor affecting the students' participation level [23, 24, 43, 44, 45, 46, 47, 48]. Specifically, Giannini-Gachago and Seleka [48] note that the gender factor was the major influencing variable for participation patterns in terms of both quantity and quality. As to the positive effect of parental educational level, related studies report that the students' participation level is not directly correlated with parental educational level but by factors that are related with this, such as parents' involvement in their students' learning process or parents' emphasis on cognitive and social learning activities $[49,50,51]$. Studies on selection effects and patterns of participation and interaction promise to offer insights into the social and educational effects of social Web applications on learners. This study only considers a dataset, which was collected in June 2012. Patterns of interaction in social Web applications undoubtedly change rapidly each year. "Widespread adoption of social network technologies suggests that traditional digital divide indicators will be less meaningful in the near future" is noted in the Ahn paper [47]. Finally, continued research is needed because we need to examine study suggestions and parameters, such as: (a) the teachers' role in this research process and the training in the use of digital technologies, (b) the recognition of the limitations, and also (c) the need to continue to explore the issue with other sample of high school students from various places of Greece.

\section{References}

[1] P. N. Chou and H. H. Chen, Engagement in online collaborative learning: A case study using a Web 2.0 tool, Journal of Online Learning and Teaching, 4(4), 2008, 574-582.

[2] A. Nevgi, P. Virtanen, and H. Niemi, Supporting students to develop collaborative learning skills in technology-based environments, British journal of educational technology, 37(6), 2006, 937-947.

[3] Y. Woo, and T.C. Reeves, Meaningful interaction in web-based learning: A social constructivist interpretation, The Internet and Higher Education, 10(1), 2007, 15-25.

[4] T. Scott, M. Cole, and M. Engel, Computers and education: A cultural constructivist perspective, Review of Research in Education, $18,1992,191-251$.

[5] C. Kynigos, Niches for Constructionism: forging connections for practice and theory, Proc. Conf. on Constructionism 2012, Theory, practice and impact, Greece, 2012, 40-51.

[6] C. McRobbiea, and K. Tobin, A social constructivist perspective on learning environments, International Journal of Science Education, 19 (2), 1997, $193-208$.

[7] T. Cerratto, and H. Rodriguez, Studies of Computer Supported Collaborative Writing. Implications for System Design. In COOP, 2002, 139-154.

[8] S. Bennett, A. Bishop, B. Dalgarno, J. Waycott, and G. Kennedy, Implementing Web 2.0 technologies in higher education: A collective case study, Computers \& Education, 59(2), 2012, 524-534.

[9] C. Greenhow, B. Robelia, and J. E. Hughes, Learning, Teaching, and Scholarship in a Digital Age Web 2.0 and Classroom Research: What Path Should We Take Now?, Educational Researcher, 38(4), 2009, 246-259.

[10] C. Redecker, K. Ala-Mutka, M. Bacigalupo, A. Ferrari, and Y. Punie, Learning 2.0: The impact of Web 2.0 innovations on education and training in Europe. Final Report, European Commission- Joint Research Center- Institute for Prospective Technological Studies, Seville, 2009, URL: ftp://ftp.jrc.es/pub/EURdoc/EURdoc/JRC55629.pdf

[11] L. Lockyer, and J. Patterson, Integrating social networking technologies in education: a case study of a formal learning environment, In Advanced Learning Technologies, Proc. 9th IEEE Conf. ICALT'08, 2008, 529-533.

[12] S. Dawson, A study of the relationship between student social networks and sense of community, Educational Technology \& Society, 11(3), 2008, 224-238.

[13] E. Klopfer, S. Osterweil, J. Groff, and J. Haas, Using the technology of today in the classroom today: The instructional power of digital games, social networking, and simulations and how teachers can leverage them. The Education Arcade, 2009, URL:http://education.mit.edu/papers/GamesSimsSocNets EdArcade.pdf

[14] E. Romero-Frías, and J. L. Arquero Montaño, Exploring the use of Social Network Sites on accounting education: A social constructivist approach, URL: http://personal.us.es/arquero/jornada/docs/25.pdf

[15] J. Zhang, Comments on Greenhow, Robelia, and Hughes: toward a creative social web for learners and teachers, Educational Researcher, 38(4), 2009, 274-279. 
[16] N. Michinov, S. Brunot, O. Le Bohec, J. Juhel, and M. Delaval, Procrastination, participation, and performance in online learning environments. Computers \& Education, 56(1), 2011, 243-252.

[17] S. Vonderwell, and S. Zachariah, Factors that Influence Participation In Online Learning. Journal of Research on Technology in education, 38(2), 2005.

[18] S. Hrastinski, A theory of online learning as online participation, Computers \& Education, 52(1), 2009, 78-82.

[19] Diigo, URL: http://www.diigo.com

[20] E. Exarchou, and Aik. Klonari, Analyzing Sociocultural Constructivist Interactions of Students during Geographical and Environmental Research Project in the social Web 2.0. A Case Study of Greek High School Students, IOSR Journal Of Humanities And Social Science (IOSR-JHSS), 19(2), 2014, 55-61.

[21] C. Vrasidas, and M.S. McIsaac, Factors influencing interaction in an online course, American Journal of Distance Education, 13(3) $1999,22-36$.

[22] S. J. Godwin, , M. S. Thorpe, and J. T. E. Richardson, The impact of computer- mediated interaction on distance learning, British Journal of Educational Technology, 39(1), 2008, 52- 70.

[23] E. Yukselturk, and E. Top, Exploring the link among entry characteristics, participation behaviors and course outcomes of online learners: An examination of learner profile using cluster analysis, British Journal of Educational Technology, 44(5), 2013, 716-728.

[24] D. R. Montello, K. L. Lovelace, R. G. Golledge, and C. M. Self, Sex-related differences and similarities in geographic and environmental spatial abilities. Annals of the Association of American Geographers, 89(3), 1999, 515-534.

[25] A. Klonari, A. Dalaka, and T. Petanidou, How evident is the apparent? Students' and teachers' perceptions of the terraced landscape, International Research in Geographical and Environmental Education, 20(1), 2011, 5-20.

[26] E. Apostolopoulou, and A. Klonari, Children's map Redding habilities in relation to distance perception, travel time and landscape, European Journal of Geography, 2(2), 2011, 35-47.

[27] W. W. Beatty, and A. I. Tröster, Gender differences in geographical knowledge. Sex Roles, 16(11-12), 1987, 565-590.

[28] K. J. Bryant, Personality correlates of sense of direction and geographic orientation, Journal of personality and social psychology, 43(6), 1982, 1318.

[29] A. Black, Spatial ability and earth science conceptual understanding, Journal of Geoscience Education, 53(4), $2005,402$.

[30] P. P. Gilmartin, and J. C. Patton, Comparing the sexes on spatial abilities: Map-use skills. Annals of the Association of American Geographers, 74(4), 605-619.

[31] E. Exarchou, and Aik. Klonari, A pre-study on the Use of Web 2.0 Social Networking Technologies in Geographical and Environmental Learning for Sustainability of Greek Secondary Students, Proc. 13th International Conf. on Environmental Science and Technology (CEST), Greece, 2013256.

[32] E. Exarchou, and Aik. Klonari, Using a Social Bookmarking Systems to enhance the Environmental and Geographical Learning of secondary students. A pre- study review, Proc. Conf. on Constructionism 2012, Theory, practice and impact, Greece, $2012,671$.

[33] Netminer, URL: http://www.netminer.com/images/NetMiner4 E.pdf

[34] L. Vygotsky, Mind in Society (London: Harvard University Press, 1978).

[35] M. Lucas, C. Gunawardena, and A. Moreira, Assessing social construction of knowledge online: A critique of the interaction analysis model. Computers in Human Behavior, 30, 2014, 574-582.

[36] E. von Glasersfeld, Radical constructivism: A way of knowing and learning (London: Falmer,1995).

[37] T. Scott, M. Cole, and M. Engel, Computers and education: A cultural constructivist perspective, Review of Research in Education, $18,1992,191-251$.

[38] C. Kynigos, Niches for Constructionism: forging connections for practice and theory, Proc. Conf. on Constructionism 2012, Theory, practice and impact, Greece, 2012, 40-51.

[39] E. Klein, and E. Merritt, Environmental Education as a Model for Constructivist Teaching, The Journal of Environmental Education, 25 (3), 1994, 14-21.

[40] C. McRobbiea, and K. Tobin, A social constructivist perspective on learning environments, International Journal of Science Education, 19 (2), 1997, $193-208$.

[41] D. Jonassen, K. Peck, and B. Wilson, Learning with technology: A constructivist perspective. (Eds.), Special Education Technology, 16, Prentice Hall, 1999.

[42] G. Liarakou, I. Athanasiadis, and C. Gavrilakis, What Greek Secondary School Students Believe about Climate Change? International Journal of Environmental and Science Education, 6(1), 2011, 79-98.

[43] F. P rinsen, M. L. L. Volman, and J. Terwel, The influence of learner characteristics on degree and type of participation in a CSCL environment, British Journal of Educational Technology, 38(6), 2007, 1037-1055.

[44] Arbaugh, J. B. (2000). An exploratory study of the effects of gender on student learning and class participation in an Internet-based MBA course, Management Learning, 31(4), 503-519.

[45] S. R. Aragon, and E. S. Johnson, Factors influencing completion and noncompletion of community college online courses, The Amer. Jrnl. of Distance Education, 22(3), 2008, 146-158.

[46] T. Volery, and D. Lord, Critical success factors in online education, International Journal of Educational Management, 14(5), 2000, 216-223.

[47] J. Ahn, Digital divides and social network sites: Which students participate in social media? Journal of Educational Computing Research, 45(2), 2011, 147-163.

[48] D. Giannini-Gachago, and G. Seleka, Experiences with international online discussions: Participation patterns of Botswana and American students in an Adult Education and Development course at the University of Botswana. International Journal of Education and Development using Information and Communication Technology (IJEDICT), 1 (2), 2005, $163-184$.

[49] D. A. Kodde, and J. M. Ritzen, Direct and indirect effects of parental education level on the demand for higher education, Journal of Human Resources, 1988, 356-371.

[50] R. K. Toutkoushian, and T. Curtis, Effects of socioeconomic factors on public high school outcomes and rankings, The Journal of Educational Research, 98(5), 2005, 259-271.

[51] R. Junco, The relationship between frequency of Facebook use, participation in Facebook activities, and student engagement, Computers \& Education, 58(1), 2012, 162-171. 